\title{
A térd- és lábszársérülések okozta országos epidemiológiai és egészségbiztosítási betegségteher Magyarországon
}

\author{
Varga Veronika ${ }^{1}$. Elmer Diána ${ }^{1,2}$. Boncz Imre dr., ${ }^{1,2}$ - Sipos Dávid ${ }^{3,4}$ \\ Kajos Luca Fanni ${ }^{1}$ - Sebestyén Andor dr. ${ }^{1,2}$ - Molics Bálint dr. ${ }^{5}$ \\ ${ }^{1}$ Pécsi Tudományegyetem, Egészségtudományi Kar, Egészségbiztosítási Intézet, Pécs \\ ${ }^{2}$ Pécsi Tudományegyetem, Egészségtudományi Kar, \\ Real World \& Big Data Egészség-gazdaságtani Kutatóközpont, Pécs \\ ${ }^{3}$ Pécsi Tudományegyetem, Egészségtudományi Kar, Képalkotó Diagnosztikai Tanszék, Kaposvár \\ ${ }^{4}$ Somogy Megyei Kaposi Mór Oktató Kórház, Dr. Baka József Diagnosztikai, \\ Onkoradiológiai, Kutatási és Oktatási Központ, Kaposvár \\ ${ }^{5}$ Pécsi Tudományegyetem, Egészségtudományi Kar, Fizioterápiás és Sporttudományi Intézet, Pécs
}

Bevezetés: A térd és a lábszár sérülései jelentős terhet jelentenek az egyén és a társadalom számára.

Célkitüzés: Elemzésünk célja volt a térd- és lábszársérülés okozta éves epidemiológiai és egészségbiztosítási betegségteher vizsgálata Magyarországon.

Adatok és módszerek: Az elemzésben felhasznált adatok a Nemzeti Egészségbiztosítási Alapkezelő (NEAK) finanszírozási adatbázisából származnak, és a 2018. évet fedik le. Vizsgáltuk az éves egészségbiztosítási kiadásokat, azok megoszlását, az éves betegszámot, valamint a 100000 lakosra vetített prevalenciát korcsoportok és nemek szerinti bontásban. A térd és a lábszár sérülései kórképeket a Betegségek Nemzetközi Osztályozása (BNO, 10. revízió) szerinti S80-S89-es kóddal azonosítottuk.

Eredmények: A legköltségesebb ellátási forma az aktívfekvőbeteg-szakellátás volt, amelynek országos betegszáma öszszesen 18398 fó (9868 fó férfi, 8530 fó nő) volt. Az aktívfekvőbeteg-szakellátás betegforgalmi adatai alapján a 100000 före eső prevalencia a férfiaknál 211,2 fó, a nőknél 167,0 fó, együtt 188,1 fő volt. A NEAK 8,808 milliárd Ft-ot költött 2018-ban a térd- és lábszársérülések kezelésére, ami 32,59 millió USD-nak, illetve 27,62 millió EURnak felelt meg. Az aktívfekvőbeteg-szakellátás a teljes egészségbiztosítási kiadás 61,4\%-ával volt a legmeghatározóbb költségelem. A kiadások 52,0\%-a férfiaknál, míg 48,0\%-a nóknél jelent meg. A 49. életévig a férfiak, míg az 50. életév feletti korosztályban a nők sérüléseiból származó ellátások betegszámai és költségei a magasabbak.

Következtetés: Az aktívfekvőbeteg-szakellátás bizonyult a fő költségtényezőnek. A betegség előfordulási gyakorisága 26\%-kal volt magasabb a férfiak esetében, mint a nóknél.

Orv Hetil. 2021; 162(Suppl 1): 54-60.

Kulcsszavak: térd- és lábszársérülés, betegségteher, egészségbiztosítás, finanszírozás, aktívfekvőbeteg-szakellátás

The nationwide epidemiological and health insurance disease burden of knee and lower leg injuries in Hungary

Introduction: Injuries to the knee and lower leg pose a great burden for the individual and society.

Objective: The aim of our study was to determine the annual epidemiological disease burden and the health insurance treatment cost of knee and lower leg injuries in Hungary.

Data and methods: Data were derived from the financial database of the National Health Insurance Fund Administration (NHIFA) of Hungary for the year 2018. The data analysed included annual health insurance costs and their distribution and annual patient numbers and prevalence per 100000 population calculated for age groups and sex. Patients with knee and lower leg injuries were identified with the following code of the International Classification of Diseases, 10th revision: S80-S89.

Results: The most expensive insurance treatment category was acute inpatient care, presenting 18398 patients in total (9868 men, 8530 women). Based on patient numbers in acute inpatient care, the prevalence in 100000 population among men was 211.2 patients, among women 167.0 patients, in total 188.1 patients. In 2018, NHIFA spent 8.808 billion HUF on the treatment of patients with knee and lower leg injuries (32.59 million USD, 27.62 million 
EUR). Acute inpatient care with $61.4 \%$ of the total health insurance expenditure was the main cost driver. $52.0 \%$ of the costs was spent on the treatment of male, while $48.0 \%$ on female patients. Until the age of 49 , the number of patients and their costs were higher for men, while those over the age of 50 were higher for women.

Conclusion: Acute inpatient care was the major cost driver. The prevalence of the disease was by $26 \%$ higher in men compared to women.

Keywords: knee and lower leg injuries, disease burden, health insurance, financing, acute inpatient care

Varga V, Elmer D, Boncz I, Sipos D, Kajos LF, Sebestyén A, Molics B. [The nationwide epidemiological and health insurance disease burden of knee and lower leg injuries in Hungary]. Orv Hetil. 2021; 162(Suppl 1): 54-60.

(Beérkezett: 2021. január 4.; elfogadva: 2021. január 20.)

\section{Rövidítések}

BNO = Betegségek Nemzetközi Osztályozása; CT = $($ computed tomography) komputertomográfia; EFOP $=($ Emberi Erőforrás Fejlesztési Operatív Program; MRI = (magnetic resonance imaging) mágnesesrezonancia-képalkotás; NEAK = Nemzeti Egészségbiztosítási Alapkezelő; PET = pozitronemissziós tomográfia

A térd- és lábszársérülésekkel kapcsolatosan korlátozottan állnak rendelkezésünkre naprakész betegségteherelemzések. A felnőtt népesség körében gyakoriak az alsó végtagot érintő sérülések, amelyek a munkateljesítményt és az életminőséget negatívan befolyásolhatják, ezáltal nemcsak az egyén, hanem a társadalom szempontjából is jelentős terhet okozhatnak [1-4].

A térd és a lábszár régióit az első 5 leggyakoribb sérülést szenvedő testrész között tartják számon a világon. A legtöbb diszlokációs típusú sérülés (rándulás, ficam) a térdre jellemző [5], míg a térdízülettől távolabb elhelyezkedő területeken inkább a törések száma gyakoribb, melyek mintegy egyharmadánál mütéti beavatkozás is indokolt [6]. Számos kutatás foglalkozott az ezeket a régiókat érintő sérülések vonatkozásában az életkor és nemek szerinti előfordulás gyakorisága és típusa közötti összefüggések vizsgálatával [6-9]. A térd vagy a térd alatti sérülések fóleg a fiatalabb korosztályt érintik, 100000 före vetített incidenciájuk 98 volt az Egyesült Királyságban [7]. Az Amerikai Egyesült Államok sürgősségi osztályain évente ellátott mintegy 31 millió eset felét pedig szintén a végtagsérülések tették ki [10]. A sérülést előidéző leggyakoribb okok közé tartozik a csúszásból, elesésből, extrém sportból, valamint közlekedési balesetből bekövetkező alsó végtagi történések, jellemzően fiatal férfiaknál $[2,11]$. A közúti forgalomban bekövetkezó balesetekben alsó végtagi sérülést elszenvedő személyek föleg a gyalogosok, illetve a motoron közlekedő utasok [12-15]. Ugyanígy elmondható, hogy a hivatásos sportolók körében is az alsó végtagot ért sérülések jelentik az egyik leggyakoribb sérüléstípust $[16,17]$.

A magasabb életkor és a nói nemnél megjelenő magas betegszám és költségteher hátterében feltételezhetően az életkorral és a nemmel összefüggésbe hozható csont- ritkulás áll. Az osteoporosisnak és nem megfelelő mértékű kezelésének következménye népegészségügyi szempontból kiemelkedő, kezelési költségei nagy terhet rónak az egészségbiztosítási rendszerekre világszerte [18]. A magas törési kockázattal rendelkező nők többsége nem részesül aktív kezelésben [19, 20]. A csontritkulás magas költsége, a kezelések hiánya és az öregedő társadalom által előidézett gazdasági teher előre jelzett növekedése ellenére a betegség gyógyszeres megelőzésének alkalmazása lényegesen alacsonyabb, mint az optimális, így javasolt az egészségpolitika megváltoztatása [21].

Európában becslések szerint 22 millió nő és 5,5 millió férfi szenved osteoporosisban [22]. Világszerte növekszik a csontritkulásból fakadó törések száma, ami egyre nagyobb terhet jelent a társadalomra. Egyes becslések szerint a 2017. évi 2,7 millióról 2030-ra 3,3 millióra fog nőni a törések száma, ami 23\%-os növekedést jelent. Ezzel párhuzamosan az erre fordított költségek 37,5 millió EUR-ról 47,4 millió EUR-ra fognak emelkedni, ami 27\%-kal több kiadást jelent [23].

Elemzésünk célja volt a térd- és lábszársérülés okozta éves országos epidemiológiai és egészségbiztosítási betegségteher meghatározása a 2018-as évre vonatkozóan Magyarországon.

\section{Adatok és módszerek}

A Nemzeti Egészségbiztosítási Alapkezelő (NEAK) az adatokat a finanszírozási adatbázisából szolgáltatta számunkra a 2018-as évre vonatkozóan. Az elemzésbe bevont, térd- és lábszársérülést szenvedő betegkört a Betegségek Nemzetközi Osztályozása (BNO) 10. revíziója szerinti S80-S89-es kóddal azonosítottuk.

Az epidemiológiai és egészségbiztosítási betegségteher vizsgálata során valamennyi ellátási formát elemeztünk, beleértve a háziorvosi ellátást, az otthoni szakápolást, a járóbeteg-szakellátást, valamint az aktív- és krónikusfekvőbeteg-szakellátást, a betegszállítást és mentést, a képalkotó diagnosztikát (komputertomográfia [CT], mágnesesrezonancia-képalkotás [MRI], pozitronemissziós tomográfia [PET]) és laboratóriumi ellátást, a gondozóintézeti gondozást, a tételes elszámolás alá eső egyszer 
használatos eszközöket, az implantátumokat, a gyógyszereket és nagy értékú mútéti eljárásokat, a gyógyszer- és gyógyászatisegédeszköz-ártámogatást.

Az aktív- és krónikusfekvőbeteg-szakellátási formán belül jelentett betegadatok esetében a NEAK kórházi (osztályos) ápolási esetről szóló adatlapjának 26. mezőjében található diagnózisok közül csak a „3. ápolást indokló fódiagnózis" tétel adatait elemeztük.

Elemzésünkben epidemiológiai oldalról meghatároztuk első lépésben az éves betegforgalmat, valamint a 100000 lakosra jutó igénybevételi prevalenciát korcsoportos és nemek szerinti bontásban. Az egyes kasszák bejelentett betegszámai közötti esetleges átfedések elkerülése érdekében a térd- és lábszársérülésekkel érintett éves betegkör meghatározására az aktívfekvőbeteg-szakellátás adatait vettük figyelembe. A prevalencia kiszámításához, valamint nem és korcsoportok szerinti bemutatásához a Központi Statisztikai Hivatalnak a magyarországi lakónépességre vonatkozó 2018. évi adatbázisát vettük alapul.

Az egészségbiztosítási betegségteher vizsgálata során meghatároztuk az egészségbiztosítási kiadásokat és a költségek megoszlását nemenkénti és korcsoportos (019; 20-29; 30-39; 40-49; 50-59; 60-69; 70+ év) bontásban is. Az egyes kasszák közötti esetleges duplikációk elkerülése érdekében az éves egészségbiztosítási kiadások és az egy foore eső kiadások vizsgálatakor a legköltségesebb egészségbiztosítási kasszát, az aktívfekvőbetegkassza adatait tekintettük meghatározónak.

Az egészségbiztosítási kiadásokat a Magyar Nemzeti Bank 2018. évi éves átlagárfolyamán adtuk meg mind az EUR (318,87 Ft/EUR), mind az USD $(270,25$
Ft/USD) esetében, hogy nemzetközi vonatkozásban is összehasonlíthatók legyenek. A 'mentés' ellátási forma esetében költségek nem álltak rendelkezésünkre, a PET vonatkozásában pedig nem jelentettek betegadatokat. Etikai jóváhagyás jelen elemzés vonatkozásában nem volt szükséges. A magyar egészségügyi rendszer felépítésének, múködésének és finanszírozásának részletes leírása máshol megtalálható [24-30].

\section{Eredmények}

Az 1. táblázat a 2018-as évben lejelentett térd- és lábszársérülést szenvedők számát és a sérüléssel összefüggő egészségbiztosítási költségeket mutatja be ellátási formánként.

A legnagyobb országos betegszámot a járóbeteg-szakellátás esetében találtuk: összesen 212292 fó. Ezt követte a háziorvosi ellátásban (87 339 fó), majd a gyógyászati segédeszközök igénybevételében (25 816 fő) található magas betegszám.

Nemek szerinti bontásban vizsgálva is hasonló az ellátási formák sorrendje. A legmagasabb betegszám a járóbeteg-szakellátáson belül volt, a férfiaknál 106058 fó, a nőknél 106234 fó. A nemek szerinti betegszám a háziorvosi ellátás keretein belül 45330 férfi és 42009 nő, a gyógyászati segédeszközök ártámogatása esetében 12847 férfi és 12969 nő volt.

Az 1. ábra az aktívfekvőbeteg-szakellátás keretében ellátott térd- és lábszársérülések betegszámát és 100000 lakosra vetített prevalenciáját mutatja be. Az összes betegszám tekintetében a férfiak esetében a 0-19 éves korosztályba (2356 fó), míg a nők esetében az 50-59 éves

1. táblázat |Az éves betegszám és az egészségbiztosítási kiadások alakulása a térd- és lábszársérülést szenvedők körében ellátási formánként (NEAK, 2018)

\begin{tabular}{|c|c|c|c|c|c|c|}
\hline \multirow{2}{*}{$\begin{array}{l}\text { Ellátási forma } \\
\text { (NEAK-kassza) }\end{array}$} & \multicolumn{3}{|c|}{ Betegszám (fó) } & \multicolumn{3}{|c|}{ NEAK-finanszírozás (Ft) } \\
\hline & Férfi & Nő & Együtt & Férfi & Nó & Együtt \\
\hline Háziorvosi ellátás & 45330 & 42009 & 87339 & 101906298 & 89323551 & 191229849 \\
\hline Otthoni szakápolás & 736 & 1487 & 2223 & 44458053 & 89543034 & 134001087 \\
\hline Betegszállítás & 3327 & 5376 & 8703 & 91089157 & 132247937 & 223337095 \\
\hline Mentés & 4766 & 5773 & 10539 & - & - & - \\
\hline Járóbeteg-szakellátás & 106058 & 106234 & 212292 & 1014785581 & 960913171 & 1975698752 \\
\hline Gondozóintézeti gondozás & 9 & 12 & 21 & 79520 & 95354 & 174874 \\
\hline Laboratóriumi ellátás & 3700 & 3152 & 6852 & 5428060 & 4271901 & 9699961 \\
\hline $\mathrm{CT}, \mathrm{MRI}$ & 4045 & 3727 & 7772 & 79367331 & 67674568 & 147041899 \\
\hline PET & 0 & 0 & 0 & 0 & 0 & 0 \\
\hline Aktívfekvőbeteg-szakellátás & 9868 & 8530 & 18398 & 2866754067 & 2540567513 & 5407321581 \\
\hline Krónikusfekvőbeteg-szakellátás & 330 & 492 & 822 & 64430190 & 91829100 & 156259290 \\
\hline Tételes elszámolás & 1 & 0 & 1 & 71 & 0 & 71 \\
\hline Gyógyszer-ártámogatás & 12814 & 12740 & 25554 & 17674497 & 18049136 & 35723633 \\
\hline Gyógyászati segédeszközök ártámogatása & 12847 & 12969 & 25816 & 296006421 & 231883955 & 527890376 \\
\hline Összesen & - & - & - & 4581979247 & 4226399221 & 8808378468 \\
\hline
\end{tabular}

CT = komputertomográfia; MRI = mágnesesrezonancia-képalkotás; NEAK = Nemzeti Egészségbiztosítási Alapkezelő; PET = pozitronemissziós tomográfia 


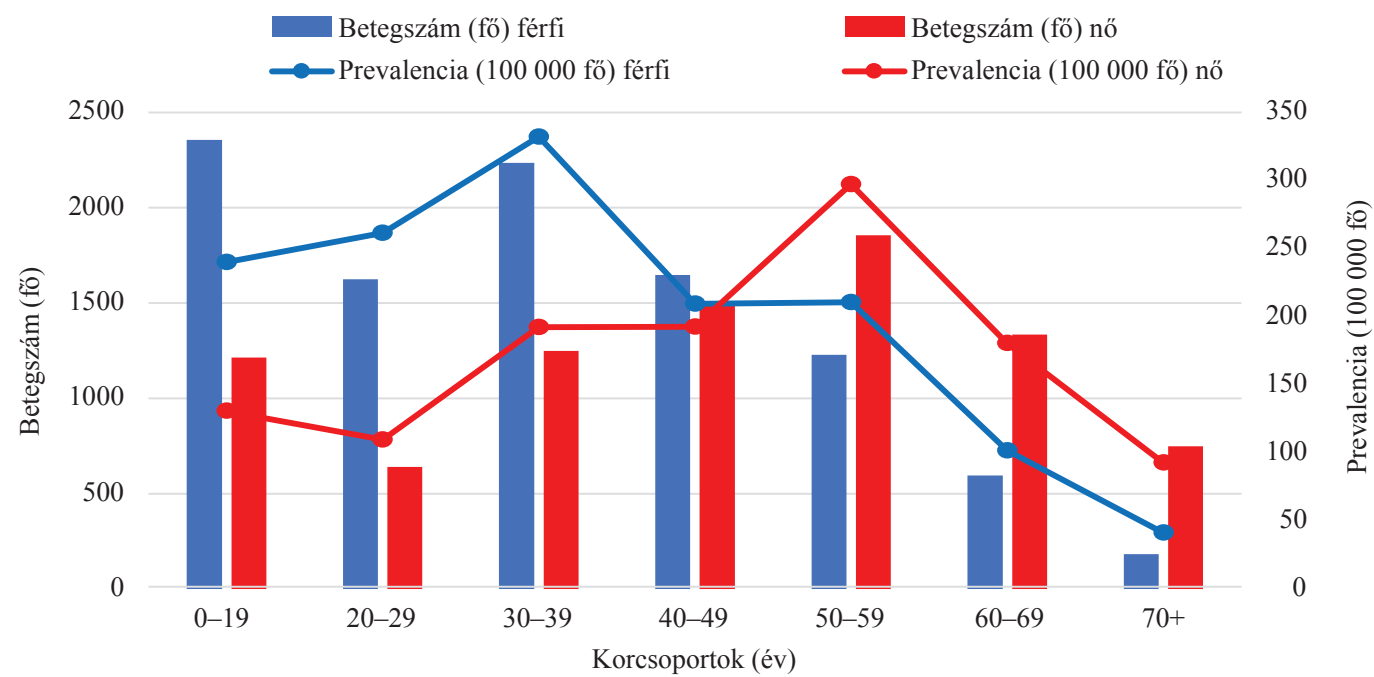

\begin{tabular}{l|l} 
1. ábra & $\begin{array}{l}\text { Az aktívfekvőbeteg-szakellátás keretében ellátott térd- és lábszársérülések betegszáma és } 100000 \text { lakosra vetített prevalenciája (NEAK, 2018) } \\
\text { NEAK = Nemzeti Egészségbiztosítási Alapkezelő }\end{array}$
\end{tabular}

korosztályba (1856 fó) tartozók betegszáma volt a legmagasabb. A betegszámok 100000 lakosra jutó prevalenciája az aktívfekvőbeteg-szakellátás betegforgalmi adatai alapján 211,2 fó volt a férfiak és 167,0 fó a nók esetében (együtt 188,1 fó). A betegszámok 100000 lakosra jutó prevalenciája az aktívabb életet élő korosztályokban minden esetben a férfiak körében, míg az idősebb korcsoportokban a nők esetében volt magasabb. A 100000 lakosra jutó betegszám tekintetében a férfiaknál a három legnagyobb betegszám a 30-39 (332 fó), a 20-29 (262 fó) és a 0-19 (240 fó) éves korcsoportok esetében figyelhető meg. A többi korcsoportban ennél kevesebbet, a 40-49 éves betegeknél 210 fót, az 50-59 éveseknél 211 föt, a 60-69 éveseknél 102 föt, a 70 év felettieknél pedig mindössze 41 fót tartottak számon.

A nőknél a 100000 lakosra jutó betegforgalmi adatok vizsgálatakor a három legkiemelkedőbb betegszámot az 50-59 éves (297 fó), a 30-39 éves (192 fó) és a 40-49 éves (193 fó) korcsoportban kaptuk. A többi korcsoportban a betegszámok alakulása a következő volt: 0-19 év: 131 fö; 20-29 év: 110 fö; 60-69 év: 180 fö; 70 év felett: 93 fó.

A térd- és lábszársérülés éves egészségbiztosítási költségeit az 1. táblázat összegzi kasszánként. A térd- és lábszársérülést szenvedők kezelésére a NEAK 8,808 milliárd Ft-ot (32 593445 USD/27 623729 EUR) fordított 2018-ban. A legmagasabb költségtételt az aktívfekvőbeteg-szakellátás (5,407 milliárd Ft), a járóbeteg-szakellátás (1,976 milliárd Ft) és a gyógyászati segédeszközök ártámogatása $(0,528$ milliárd $\mathrm{Ft})$ jelentette.

A legköltségesebb ellátási formák mindkét nem esetében a következők voltak: aktívfekvőbeteg-szakellátás $(2,867$ milliárd Ft a férfiaknál és 2,54l milliárd Ft a nőknél), járóbeteg-szakellátás (1,015 milliárd Ft a férfiaknál és 0,961 milliárd Ft a nőknél), a gyógyászati segédeszközök ártámogatása $(0,296$ milliárd Ft a férfiaknál és 0,232 milliárd Ft a nőknél).
A NEAK által támogatott ellátások költségei között jelentős különbséget tapasztaltunk, melyet a 2. ábra szemléltet. A NEAK összes kiadásának 61,4\%-a az aktívfekvőbeteg-szakellátásban $(62,6 \%$ a férfiaknál és $60,1 \%$ a nőknél), 22,4\%-a a járóbeteg-szakellátásban $(22,1 \%$ a férfiaknál és 22,7\% a nóknél), míg 6,0\%-a a gyógyászati segédeszközök ártámogatásában $(6,5 \%$ a férfiaknál és $5,5 \%$ a nőknél) jelent meg. Az összes többi egészségügyi ellátási forma részesedése 10,2\% (férfiaknál 8,8\%, nőknél $11,7 \%)$ volt.

A térd- és lábszársérüléshez kapcsolódó összes és 100000 lakosra vetített egészségbiztosítási kiadás kor és nem szerinti megoszlását a 3. ábra foglalja össze. Az egészségbiztosítási kasszák összkiadását figyelembe véve a legnagyobb kiadást a férfiak körében a 0-19 éves (1,071 milliárd Ft) és a 30-39 éves betegek $(0,961$ mil-

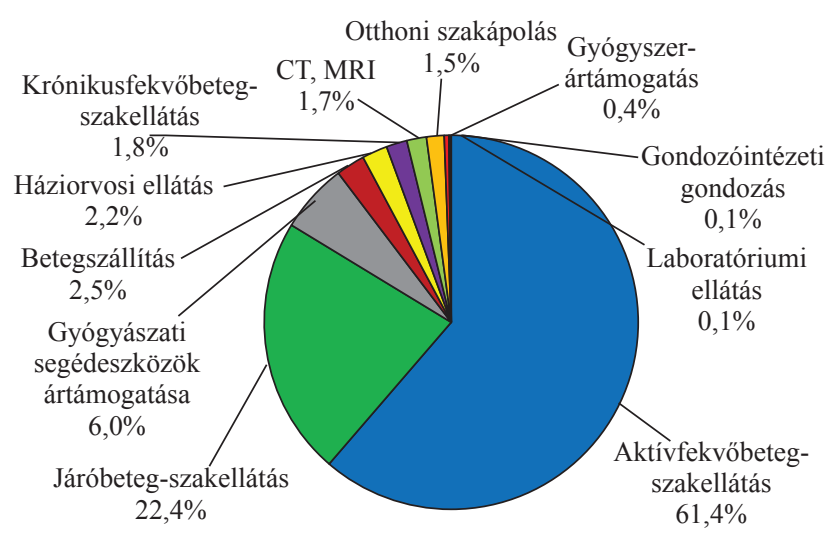

2. ábra

A térd- és lábszársérüléshez köthető éves egészségbiztosítási kezelési költségek megoszlása a NEAK-kasszák között (NEAK, 2018)

$\mathrm{CT}$ = komputertomográfia; $\mathrm{MRI}$ = mágnesesrezonancia-képalkotás; NEAK = Nemzeti Egészségbiztosítási Alapkezelő 


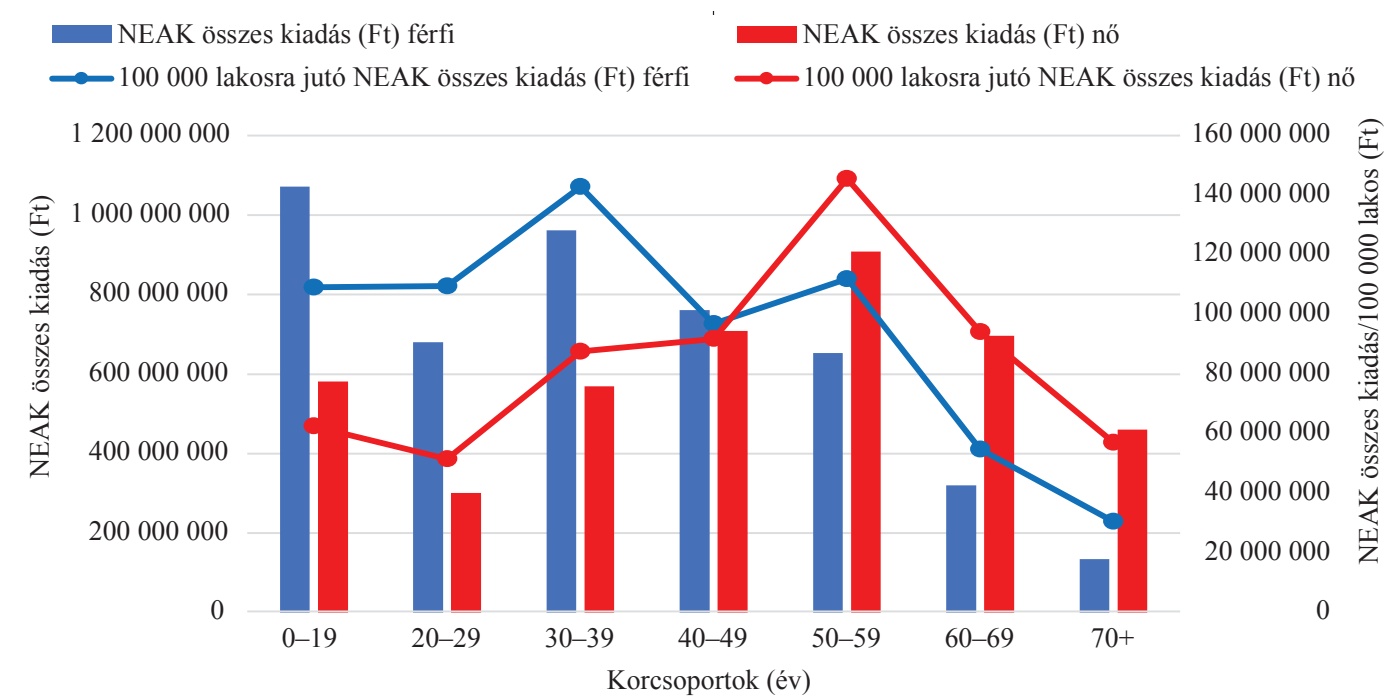

3. ábra

A térd- és lábszársérülés okozta összes és 100000 lakosra vetített egészségbiztosítási kiadás megoszlása korcsoportok és nemek szerint (NEAK, 2018)

NEAK = Nemzeti Egészségbiztositási Alapkezeló

liárd Ft) jelentették. A férfiaknál az idősebb korcsoportok esetében csökkenő kiadási tendencia látható.

A nőknél a 20-29 éves korcsoport után jelentősen emelkedett a kiadások mértéke az életkor előrehaladtával, az itt megjelenő legmagasabb költséget az 50-59 éveseknél találtuk (0,908 milliárd Ft). A 40-49 évesek mindkét nem vonatkozásában közel azonos mértékben terhelték a kasszát - férfiak: 0,761 milliárd Ft, nők: 0,709 milliárd Ft. A 100000 lakosra vetített összkiadás esetében a legnagyobb költséget az 50-59 éves nőknél (145 $529910 \mathrm{Ft}$ ), valamint közel azonos ráfordítással a 30-39 éves férfiaknál (142 814565 Ft) tapasztaltuk. Az összes kiadás 52,0\%-a férfiaknál, míg 48,0\%-a nóknél jelent meg.

\section{Megbeszélés}

Kutatásunkban a 2018-as évben elszenvedett térd- és lábszársérülések okozta egészségbiztosítási kiadásokat, valamint a sérülések előfordulási gyakoriságát vizsgáltuk Magyarországon. A különböző betegségek prevalenciájának ismerete, valamint az egészségügyi ellátások költségelemzései nélkülözhetetlenek a hazai egészségügyi ellátórendszer még gazdaságosabb, még hatékonyabb tervezéséhez [31-33].

A sérülések ellátása a gyakorlatban nagyrészt mútéti úton, az aktívfekvőbeteg-szakellátás keretében történik [34]. A kórházi ellátásra szoruló térd- és lábszársérülést szenvedőknek a kórházat elhagyva általában további, akár éveken át tartó gondozásra, kezelésre is szülkségüik lehet. A hosszas ápolási és rehabilitációs idő mind a fiatal, mind az időskorú lakosság tekintetében további költségeket generálhat $[3,21,35,36]$. A járóbeteg-szakellátási forma esetében az előzó évben mütéten átesett betegek is bejelentésre kerülhetnek, ezért vizsgálatunkban az aktívfekvőbeteg-szakellátás betegforgalmi és egészségbiztosítási adatait tekintettük meghatározónak.

Összességében elmondható, hogy az aktívfekvőbetegszakellátásban a betegszámok nemtől és kortól függetlenül arányosak az egészségbiztosítási kassza kiadásaival [37, 38]. Ám a térd- és lábszársérülések becsült prevalenciája nemenként és korcsoportonként az aktívfekvőbeteg-szakellátáson belül változatos képet mutat. A 100000 lakosra vetített prevalencia az aktívfekvőbeteg-szakellátásban szemlélteti, hogy a férfinem esetében a 0-39 éves korosztály betegszáma majdnem a kétszerese az ugyanezen korcsoportba tartozó női betegszámnak. A különbség feltételezhetően az aktív korú férfiak életviteléből, fizikai aktivitásából, extrémebb szabadidős tevékenységéből származik. Ugyanakkor az idősebb korosztályok esetében megfordul ez a tendencia: a férfiak sérüléseinek előfordulási gyakorisága és egészségbiztosítási költsége idősebb korban alacsonyabb tendenciát mutat $[7,8,39,40]$. A női nem esetében a magasabb életkorral arányosan nőtt a betegszám és az ahhoz kapcsolódó költségek is, amit a csontritkulással hozhatunk összefüggésbe. Molics és mtsai a térd- és lábszársérülést követő fizioterápiás tevekénységek 10000 före jutó esetszámának vizsgálatát végezték el adott évben. Férfiak esetében 927,64, nők esetében pedig 668,25 volt a 10000 före vetített betegszám. Eredményeikkel összhangban megállapíthatjuk mi is, hogy a 15-49 éves korosztályban a férfiak betegszáma, míg idősebb korban a nők értékei bizonyultak magasabbnak [41].

Norvég kutatók megállapították, hogy a sérülések teljes költségének mintegy 41\%-át az otthoni és a szabadidős tevékenységekből fakadó elesések okozzák. Kutatásunkkal ellentétben az itt megjelenő kórházi ellátás költségei összességében magasabbak voltak a nők esetében, mint a férfiaknál [42]. 
Az elöregedő társadalom világszerte egyre nagyobb népegészségügyi problémát jelent. Hazánkban is megfigyelhető, hogy a fiatalabb korosztály létszáma fokozatosan csökken, míg a 65 év feletti korosztályé folyamatosan nő. A társadalom idősödésével a krónikus népbetegségek, így a csontritkulás előfordulásának aránya is emelkedik. Csontanyagcsere-betegségben az idősebb népesség korosztályai, azon belül is főleg a nők érintettek [43]. Magyarországon közel egymillióan szenvednek a betegségben, mely nagyjából 600000 nőt és 300000 férfit érint. Eredményeinkből kiderült, hogy az 50 éves és afeletti korosztályba tartozó nók esetében lényegesen több volt az aktívfekvő́beteg-szakellátás keretein belül ellátott betegek száma, mint a férfiaké. A nagy geriátriai szindrómák egyike az elesés, amely gyakori előidézője az időskorú lakosság traumás töréseinek. Az ebből fakadó sérülések súlyossága miatt számos idős ember hosszas kórházi ápolást igényel [44-46]. Az Amerikai Egyesült Államokban 2015-ben 2,5 millió időskorú sérülést szenvedőt kezeltek sürgősségi osztályon, akik közül 734000 fö hoszszú távú kórházi ellátásra szorult [47]. Ugyanezen évben az időskorú lakosság egészségügyi költségei meghaladták az 50 USD-t [48]. Az Egyesült Államokban a traumás sérülést szenvedő páciensek fekvőbeteg-osztályon történő gondozásának költsége éves szinten növekedést mutatott. 10 év alatt több mint a kétszeresére emelkedett a traumás esetek kezelési költsége (12,0 milliárd USD - 29,1 milliárd USD) [49] - ehhez hasonló változásról számoltak be Tajvan területén is $(45,6$ millió USD - 86 millió USD) [50].

Kutatásunk korlátaként kell említenünk, hogy a jelen tanulmányban egy évet vizsgáltunk, ezért a számok tekintetében hosszú távú következtetés nem vonható le. $\mathrm{Az}$ adott évi térd- és lábszársérülési adatokat egyben elemeztük, nem kategorizáltuk, és nem tértünk ki a sérülések okára (sportsérülések, balesetek stb.) és súlyosságára, mivel ezekre vonatkozó adat az adatbázisban érdemben nem szerepel.

Anyagi támogatás: A kézirat az „EFOP-3.6.2-16-201700009: Klinikai kutatások tematikus hálózatának kialakítása és nemzetköziesítése” projekt keretében az „Egészségbiztosítási és klinikai real-world adatvagyon hasznosítása" alprojekt támogatásával készültt.

Szerzői munkamegosztás: A vizsgálat tervezése és lefolytatása: V. V., B. I., M. B. Adatok gyújitése és ellenőrzése: V. V., B. I., S. A., M. B. Adatfeldolgozás és adatelemzés: V. V., E. D., K. L. F., M. B. Statisztikai elemzések: V. V., B. I., S. D., M. B. Az eredmények értékelése: V. V., E. D., B. I., K. L. F., S. A., M. B. Irodalomkutatás: V. V., E. D., S. D., M. B. A kézirat megszövegezése: V. V., E. D., B. I., S. D., K. L. F., S. A., M. B. A cikk végleges változatát valamennyi szerző elolvasta és jóváhagyta.

Érdekeltségek: A szerzőknek nincsenek érdekeltségeik.

\section{Köszönetnyilvánítás}

A szerzők köszönetet mondanak az „EFOP-3.6.2-16-2017-00009: Klinikai kutatások tematikus hálózatának kialakítása és nemzetköziesítése" projekt keretében nyújtott támogatásért (szakmai vezető: prof. dr. Kovács L. Gábor, a Magyar Tudományos Akadémia rendes tagja).

\section{Irodalom}

[1] van Dreumel RL, van Wunnik BP, Janssen L, et al. Mid-to longterm functional outcome after open reduction and internal fixation of tibial plateau fractures. Injury 2015; 46: 1608-1612.

[2] Sluys KP, Shults J, Richmond TS. Health related quality of life and return to work after minor extremity injuries: a longitudinal study comparing upper versus lower extremity injuries. Injury 2016; 47: 824-831.

[3] Corso P, Finkelstein E, Miller T, et al. Incidence and lifetime cost of injuries in the United States. Inj Prev. 2006; 12: 212-218.

[4] Banerjee M, Bouillon B, Shafizadeh S, et al. Epidemiology of extremity injuries in multiple trauma patients. Injury $2013 ; 44$ : 1015-1021.

[5] Mack CD, Kent RW, Coughlin MJ, et al. Incidence of lower extremity injury in the National Football League: 2015 to 2018. Am J Sports Med. 2020; 48: 2287-2294.

[6] Vestergaard V, Pedersen AB, Tengberg PT, et al. 20-year trends of distal femoral, patellar, and proximal tibial fractures: a Danish nationwide cohort study of 60,823 patients. Acta Orthop. 2020; 91: 109-114

[7] Lambers K, Ootes D, Ring D. Incidence of patients with lower extremity injuries presenting to US emergency departments by anatomic region, disease category, and age. Clin Orthop Relat Res. 2012; 470: 284-290.

[8] Scholes S, Panesar S, Shelton NJ, et al. Epidemiology of lifetime fracture prevalence in England: a population study of adults aged 55 years and over. Age Ageing 2014; 43: 234-240.

[9] Larsen P, Court-Brown CM, Vedel JO, et al. Incidence and epidemiology of patellar fractures. Orthopedics 2016; 39: el154el158.

[10] Bergen G, Chen LH, Warner M, et al. Injury in the United States: 2007 Chartbook. National Center for Health Statistics, Hyattsville, MD, 2008.

[11] DeFroda SF, Gil JA, Owens BD. Epidemiology of lower extremity injuries presenting to the emergency room in the United States: snow skiing vs. snowboarding. Injury 2016; 47: 22832287.

[12] Elliott MA, Baughan CJ, Sexton BF. Errors and violations in relation to motorcyclists' crash risk. Accid Anal Prev. 2007; 39: 491-499.

[13] Zambon F, Hasselberg M. Socioeconomic differences and motorcycle injuries: age at risk and injury severity among young drivers. A Swedish nationwide cohort study. Accid Anal Prev. 2006; 38: 1183-1189.

[14] Ngunde PJ, Akongnwi AC, Mefire CA, et al. Prevalence and pattern of lower extremity injuries due to road traffic crashes in Fako Division, Cameroon. Pan Afr Med J. 2019; 32: 53.

[15] Monk JP, Buckley R, Dyer D. Motorcycle-related trauma in Alberta: a sad and expensive story. Can J Surg. 2009; 52: E235E240.

[16] Mahdavi Mohtasham H, Shahrbanian S, Khoshroo F. Epidemiology and history of knee injury and its impact on activity limitation among football premier league professional referees. J Inj Violence Res. 2018; 10: 45-52.

[17] Salhab HA, Fares MY, Khachfe HH, et al. Musculoskeletal lower limb injuries in Major League Baseball. Phys Ther Sport 2019; 39: $38-43$. 
[18] Odén A, McCloskey EV, Kanis JA, et al. Burden of high fracture probability worldwide: secular increases 2010-2040. Osteoporos Int. 2015 ; 26: 2243-2248.

[19] Rodrigues AM, Eusébio M, Santos MJ, et al. The burden and undertreatment of fragility fractures among senior women. Arc Osteoporos. 2018; 13: 22.

[20] McLellan AR, Wolowacz SE, Zimovetz EA, et al. Fracture liaison services for the evaluation and management of patients with osteoporotic fracture: a cost-effectiveness evaluation based on data collected over 8 years of service provision. Osteoporos Int. 2011; 22: 2083-2098.

[21] Svedbom A, Ivergård M, Hernlund E, et al. Epidemiology and economic burden of osteoporosis in Switzerland. Arch Osteoporos. 2014; 9: 187.

[22] Hernlund E, Svedbom A, Ivergård M, et al. Osteoporosis in the European Union: medical management, epidemiology and economic burden. A report prepared in collaboration with the International Osteoporosis Foundation (IOF) and the European Federation of Pharmaceutical Industry Associations (EFPIA). Arch Osteoporos. 2013; 8: 136.

[23] Borgström F, Karlsson L, Ortsäter G, et al. Fragility fractures in Europe: burden, management and opportunities. Arch Osteoporos. 2020; 15: 59.

[24] Boncz I, Evetovits T, Dózsa Cs, et al. The Hungarian Care Managing Organization Pilot Program. Value Health Reg Issues 2015; 7: 27-33

[25] Boncz I, Vajda R, Ágoston I, et al. Changes in the health status of the population of Central and Eastern European countries between 1990 and 2010. Eur J Health Econ. 2014; 15(Suppl 1): S137-S141.

[26] Endrei D, Molics B, Ágoston I. Multicriteria decision analysis in the reimbursement of new medical technologies: real-world experiences from Hungary. Value Health 2014; 17: 487-489.

[27] Boncz I, Sebestyén A. Financial deficits in the health services of the UK and Hungary. Lancet 2006; 368: 917-918.

[28] Eisingerné Balassa B, Csákvári T, Ágoston I. Health insurance pharmaceutical expenditures in Hungary. [Az egészségbiztosítási gyógyszerkiadások alakulása Magyarországon.] Orv Hetil. 2019; 160(Suppl 1): 49-54. [Hungarian]

[29] Boncz I, Kaló Z, Mohamed Ibrahim MI, et al. Further steps in the development of pharmacoeconomics, outcomes research, and health technology assessment in Central and Eastern Europe, Western Asia, and Africa. Value Health Reg Issues 2013; 2: 169-170.

[30] Boncz I, Nagy J, Sebestyén A, et al. Financing of health care services in Hungary. Eur J Health Econ. 2004; 5: 252-258.

[31] Dózsa Cs, Szeberin Z, Sótonyi P, et al. The territorial distribution of amputations in healthcare and social context in Hungary in 2016-2017. [Az amputációk területi gyakorisága társadalmi és ellátórendszeri összefüggésben Magyarországon 2016-2017ben.] Orv Hetil. 2020; 161: 747-755. [Hungarian]

[32] Varga V, Boncz I, Sebestyén A, et al. Utilization indicators of balneotherapy in Hungary. [A gyógyfürdőellátások igénybevételi mutatói Magyarországon.] Orv Hetil. 2019; 160(Suppl 1): 22 28. [Hungarian]

[33] Boncz I, Sebestyén A, Endrei D, et al. Health policy experiences of publicly financed laboratory services in Hungary with health insurance data analysis. [A közfinanszírozott laboratóriumi szolgáltatások egészségpolitikai tapasztalatai Magyarországon egészségbiztosítási adatok elemzésével.] Orv Hetil. 2020; 161: 468473. [Hungarian]
[34] Rouhani SA, Eliacin HC, Edmond MC, et al. Epidemiology of traumatic injuries presenting to an ED in Central Haiti: a retrospective cohort study. Emerg Med J. 2019; 36: 389-394.

[35] King D, Hume P, Gianotti S, et al. A retrospective review over 1999 to 2007 of head, shoulder and knee soft tissue and fracture-dislocation injuries and associated costs for rugby league in New Zealand. Int J Sports Med. 2011; 32: 287-291.

[36] Peterson C, Xu L, Florence C. Average medical cost of fatal and non-fatal injuries by type in the USA. Inj Prev. 2021; 27: 24-33.

[37] Varga V, Molics B, Gazsó T, et al. Annual health insurance treatment cost of injuries to the knee and lower leg based on routinely collected real-world financing data. Value Health 2020; 23: S219.

[38] Varga V, Molics B, Gazsó T, et al. Epidemiological disease burden of injuries to the knee and lower leg based on routinely collected health insurance claims data. Value Health 2020; 23: S225.

[39] Wennergren D, Bergdahl C, Ekelund J, et al. Epidemiology and incidence of tibia fractures in the Swedish Fracture Register. Injury 2018; 49: 2068-2074.

[40] Elsoe R, Larsen P, Nielsen NP, et al. Population-based epidemiology of tibial plateau fractures. Orthopedics 2015; 38: e780e786.

[41] Molics B, Kránicz J, Schmidt B, et al. Utilization of physiotherapy services in case of trauma disorders of the lower extremity in the outpatient care. [A fizioterápiás jellegű tevékenységek igénybevételi mutatói a járóbeteg-szakellátásban az alsó végtag traumatológiai kórképei esetében.] Orv Hetil. 2013; 154: 985-992. [Hungarian]

[42] Polinder S, Haagsma J, Panneman M, et al. The economic burden of injury: health care and productivity costs of injuries in The Netherlands. Accid Anal Prev. 2016; 93: 92-100.

[43] International Osteoporosis Foundation (2018). What is osteoporosis? Available from: https://www.iofbonehealth.org/whatis-osteoporosis [accessed: November 24, 2020].

[44] Carson M, Cook, J. A strategic approach to falls prevention. Clin Perform Qual Health Care 2000; 8: 136-141.

[45] Fuller GF. Falls in the elderly. Am Fam Physician 2000; 61: 2159-2168, 2173-2174.

[46] Bell AJ, Talbot-Stern JK, Hennessy A. Characteristics and outcomes of older patients presenting to the emergency department after a fall: a retrospective analysis. Med J Aust. 2000; 173: 179_ 182.

[47] Deileman JL, Baral R, Birger M, et al. US spending on personal health and public health, 1996-2013. JAMA 2016; 316: 26272646.

[48] Florence CS, Bergen G, Atherly A, et al. Medical costs of fatal and nonfatal falls in older adults. J Am Geriatr Soc. 2018; 66: 693-698.

[49] DiMaggio C, Ayoung-Chee P, Shinseki M, et al. Traumatic injury in the United States: in-patient epidemiology 2000-2011. Injury 2016; 47: 1393-1403.

[50] Pan RH, Chang NT, Chu D, et al. Epidemiology of orthopedic fractures and other injuries among inpatients admitted due to traffic accidents: a 10-year nationwide survey in Taiwan. Sci World Journal 2014; 2014: 637872 .

(Varga Veronika, Pécs, Vörösmarty u. 3., 7621 e-mail: veronika.varga@etk.pte.hu)

A cikk a Creative Commons Attribution 4.0 International License (https://creativecommons.org/licenses/by/4.0/) feltételei szerint publikált Open Access közlemény, melynek szellemében a cikk bármilyen médiumban szabadon felhasználható, megosztható és újraközölhetö, feltéve, hogy az eredeti szerző és a közlés helye, illetve a CC License linkje és az esetlegesen végrehajtott módosítások feltüntetésre kerülnek. (SID_1) 